ZalǫcZnilf

DOI 10.21697/zk.2020.7.12

\title{
THE BEGINNINGS OF POPULAR MUSIC STUDIES IN POLAND (HERNAS, BALCERZAN AND BARAŃCZAK)
}

LEONARdo MASI

\author{
Wydział Nauk Humanistycznych UKSW \\ Department of Humanities, \\ Cardinal Stefan Wyszyński University in Warsaw \\ leon.masi@gmail.com \\ ORCID: 0000-0003-0085-8405
}

Popular Music Studies, which in Poland have been developing fast and with very interesting results over the last few years, have not yet dealt thoroughly with sources from the area of literature studies. Nonetheless there are some works by Czesław Hernas, Edward Balcerzan, Stanisław and Anna Barańczak which can be considered part of a pre-history ${ }^{1}$ of Popular Music Studies in Poland and are worth being discussed. Even if they had, for different reasons, certain limitations, I would like to show how important the contributions from the above-mentioned literature scholars were for the development of this kind of studies.

Talking about the popular music in Poland after the Second world war, we should first of all get acquainted with two peculiarities at least. The first concerns taxonomy. In the 1968 edition of the Mała encyklopedia muzyki („Concise Encyclopaedia of Music”), published by PWM (Polskie Wydawnictwo Muzyczne - the Polish National Music Publisher), we find this statement: „it is practically impossible to distinguish light music from classical music" ${ }^{2}$. This may sound like an exaggeration, but if we look at

1 As the ending moment of this 'pre-history' I will take year 1983, when the issue of popular music was first considered on the journal „Muzyka”.

2 K. Biegański, Mała encyklopedia muzyki, ed. S. Śledziński, Warszawa 1968, p. 895. In Polish, 'muzyka rozrywkowa' ('music for entertainment', 'light music') is practically the same as 'muzyka popularna' ('popular music'). See also: L. Masi, Czym jest „muzyka lekka” i „muzyka ciężka”?, [in:] Ciężar i lekkość w kulturze. 
the Polish context, we have to admit that it presents some distinctive features. For example, a pivotal composer for Polish culture like Chopin is regarded in the world as classical, but in his homeland, he is part of the musical experience of many Poles and, as a result, his output is actually also a specific kind of Polish popular music ${ }^{3}$. Moreover, in Polish language, the word for 'composer' ('kompozytor'), is not only used for classical music writers - as usually happens in Western Europe countries - but also for popular music songwriters ${ }^{4}$. There are some other terminological aspects that show a Polish specificity in this field. Włodzimierz Sokorski, Minister of Culture from 1948 to 1956, included also rock music within the concept of 'muzyka współczesna' ('contemporary music') 5 . On the other hand, classical music, following the lines traced in the official statements, had to be 'popular'. In fact, Polish official music at the end of the 1940s consisted in mass songs used as propaganda ${ }^{6}$ (they were intended to be popular music in the sense of People's music), written by composers such as Panufnik or Lutosławski - very 'serious' names indeed to the Western ear. Another strange paradox in Polish music emerged during the 1960s, when a genre called 'poezja śpiewana' ('sung poetry'), a kind of song in which we have „lyrics which

Estetyka - poetyka - style myślenia, ed. B. Pawłowska-Jądrzyk, Warszawa 2016, pp. 35-43; R. Pasternak-Mazur, No Country for Sheer Entertainment Cultural Politics of Socialist Poland, Its Conceptual Scheme, and Vision of Popular Music, [in:] Made in Poland: Studies in Popular Music, ed. P. Gałuszka, New York - Abingdon 2020, pp. 17-36.

3 W. Panek, Mały słownik muzyki rozrywkowej, Warszawa 1986, p. 89; J. Kasperski, Fryderyk Chopin in Popular Instrumental Music, „Interdisciplinary Studies in Musicology" 2011, No. 9, pp. 357-370.

4 See for example the Wikipedia entries for popular musicians as - just to name a few - Romuald Lipko (Budka Suflera), Zbigniew Wodecki, Andrzej Smolik (Wilki), Artur Rojek (Myslovitz). None of them graduated from a Conservatory.

${ }^{5}$ Quoted after: A. Idzikowska-Czubaj, Rock w PRL-u. O paradoksach współistnienia, Poznań 2011, p. 165.

6 See: Pieśń masowa [entry], [in:] Słownik realizmu socjalistycznego, eds. Z. Łapiński, W. Tomasik, Kraków 2004; M. Sułek, Pieśni masowe o Nowej Hucie, "Zeszyty Naukowe Towarzystwa Doktorantów Uniwersytetu Jagiellońskiego. Nauki Humanistyczne" 2010, No. 1, pp. 152-160. 
were not intended to be sung"7 gained wide popularity. The success of performers such as Ewa Demarczyk, Czesław Niemen and Marek Grechuta brought into popular music poems belonging to the Polish canon, from Romanticism to contemporary poetry (Adam Mickiewicz, Cyprian Kamil Norwid, Bolesław Leśmian, etc.). Such songs were across-the-board, because they connected high and low culture. It seems - of course, bearing in mind the different political situations - that this was more or less the kind of song that Umberto Eco hoped for in Italy in 1964, a song in which „entertainment, escapism, fun, relief do not necessarily mean recklessness, automatism, in-

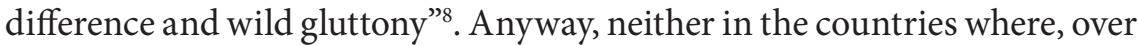
those years, Umberto Eco could see the birth of a different, more committed kind of song (France, Italy), nor in Poland, were musicologists interested in popular music. Also, Polish musicology was influenced by the German Musikwissenschaft, which embraced serious and folk music but not popular music ${ }^{9}$. This could be the reason why the first works in popular music studies came from scholars related to literary studies or from poets themselves.

The second aspect that a Western observer will find peculiar in any discourse on popular music in Poland is the different theoretical background in particular, the prolonged absence of Theodor Adorno. While, in Western Europe, the members of the Frankfurt School, often along with Antonio Gramsci, since the very beginning of this field of studies had been a constant and sometimes cumbersome presence in almost every discourse on popular music, in Poland, Adorno's essay On Popular Music was translated and published only in $2015^{10}$, whereas his Über den Fetischcharakter in der Musik

7 Z. Kloch, A. Rysiewicz, Piosenka [entry], [in:] Słownik literatury polskiej $X X$ wieku, eds. A. Brodzka, M. Puchalska, M. Semczuk, A. Sobolewska, E. Szary-Matywiecka, Wrocław - Kraków - Warszawa 1992, p. 788.

8 U. Eco, Prefazione, [in:] M. Straniero, E. Jona, S. Liberovici, G. De Maria, Le canzoni della cattiva coscienza, Milano 1964, p. 10; reprinted in: idem, Apocalittici e integrati, Milano 1964, p. 279.

9 See: M. Trochimczyk, W stronę muzykologii narodowej: Uczeni wobec muzyki polskiej, „Muzyka” 2002, No. 3-4, p. 138; R. Pasternak-Mazur, op. cit., p. 17.

10 T.W. Adorno (with G. Simpson), Muzyka popularna, transl. J. Kasperski, „Res Facta Nova” 2015, No. 16, p. 75-98. 
und die Regression des Hörens appeared in $1990^{11}$. Probably due to aversion of Leszek Kołakowski - a very influential Polish philosopher since the late 1950s, who in his Główne nurty marksizmu („Main Currents of Marxism”) almost omits Adorno and quite harshly treats Benjamin ${ }^{12}$ - most of the works by the Frankfurt School philosopher have been published in Poland only over the last decades. An important consequence of these peculiarities is that definitions and judgements on popular music given over the decades not only by Adorno, but also by scholars who in their fundamental works deal with the ideas of the German philosopher, such as Richard Middleton and Simon Frith, are useful in the Polish context only to a certain extent ${ }^{13}$.

In Poland the boundaries between serious and entertainment music were not more rigid than in other countries, but nevertheless Polish musicology didn't deal with popular music. If we look at the whole situation, it seems that there was a big distance between the perception of the boundaries at an academic level, where composers and musicologists felt they belonged to an elite (as witnessed by many articles on the journal „Ruch muzyczny”) and at non-academic level, where a very rough approach to the phenomenon of rock was adopted when this novelty began filtering into the Soviet bloc, after Stalin's death and the consequent Thaw. Around 1956, the Polish officials had to give in to jazz, which, in some way, was beginning to become the music for young people under the auspices of the party. Thus, it was from the angle of jazz that rock music was considered. In the magazine „Jazz”, we can find the statement that rock, is nothing else but the conjunction of boogie-woogie and Texas folk music, played in a very rhythmic yet primitive way"14. A wider perspective on this topic in a music journal appeared only in 1983, when a review of the first issue of the Cambridge series „Popular Music”

${ }^{11}$ Idem, Sztuka i sztuki, compiled and prefaced by K. Sauerland, transl. K. Krzemień-Ojak, Warszawa 1990.

12 L. Kołakowski, Główne nurty marksizmu, p. 3: Rozkład, Paris 1978, pp. 1066 1069; for the reception of Benjamin (and the Frankfurt School) in Poland, see also: T. Dąbrowski, The Motif of Redemption in Walter Benjamin's Early Writings, „Telos. Critical Theory of the Contemporary", 2.10.2012, https://www.telospress.com/the-motif-of-redemption-in-walter-benjamins-early-writings/ [accessed 7.05.2020].

13 M. Trochimczyk, op. cit., pp. 129-143.

14 Quoted after: A. Idzikowska-Czubaj, op. cit., p. 112. 
(Folk or Popular? Distinctions, Influences Continuities, edited by Middleton and Horn two years before) was published in „Muzyka”"15. On the following issue of the journal, from the same year, the young sociologist Tomasz Misiak published an essay titled Muzyka poważna, muzyka popularna. Dualizm współczesnej kultury muzycznej z perspektywy współczesnej socjologii muzyki („Classical music, popular music. The dualism of contemporary musical culture and the perspective of contemporary sociology of music") ${ }^{16}$. Here, for the first time, we have an account of Theodor Adorno's theories on popular music, juxtaposed by Misiak with the essay Begriff und Aestetik der 'leichten' und den 'ersten' Muzik by Vladimír Karbusický, a scholar from Czechoslovakia who emigrated to Germany in 1968, still not translated into Polish, and rather forgotten. Tomasz Misiak treats popular music more as a social than as an aesthetic phenomenon, but before the publication of his essay, as we said before, Adorno's works on popular music had remained unknown to the majority of Polish scholars, in particular literature and cultural historians. Thus, they had to come up with ideas of their own ${ }^{17}$.

The most interesting and new came at the end of the 1960s, which is not surprising, if we consider the dissemination of groups and artists of great impact - and not only on the young audience - as well as events, such the 1967 Rolling Stones' concert in Warsaw. Neither is it strange that the first striking analysis came from the field of literature studies, if we consider the popularity over that decade of the genre of 'poezja śpiewana', a kind of song with lyrics either taken from the classical authors of Polish literature, or written by extremely skilled artists like Agnieszka Osiecka or Wojciech Młynarski. In fact, the parallel analysis of poetry and song is the main topic of some works written by Edward Balcerzan (born 1937), Stanisław Barańczak (1946-2014) and Anna Barańczak (born 1945) between 1968

15 M. Kwiatkowska, „Folk or Popular? Distinctions, Influences, Continuities”, Richard Middleton i David Horn, Cambridge, London, New York, New Rochelle, Melbourne, Sydney 1981 [review], „Muzyka” 1983, Vol. 28, No. 3, pp. 133-136.

16 T. Misiak, Muzyka poważna, muzyka popularna. Dualizm wspótczesnej kultury muzycznej z perspektywy współczesnej socjologii muzyki, „Muzyka” 1983, Vol. 28, No. 4, pp. 85-108.

17 For a thorough discussion in Polish of Adorno's theories about popular music: G. Piotrowski, Muzyka popularna. Nastuchy i namysty, Warszawa 2016, pp. 42-55. 
and $1983^{18}$. These three authors belong to a generation which could have similar experiences to those of the Western countries' youth, and we will go back to them soon. In the meantime, an important contribution came from a Wroclaw University scholar of baroque literature, who belonged to the former generation and had a different background, namely Czesław Hernas (1928-2003), who in 1973 published the essay Potrzeby $i$ metody badania literatury brukowej, on the necessity of popular literature studies and about their methodology ${ }^{19}$. Contrary to Balcerzan or Barańczak, Hernas remains within the field of literature, however, from our perspective there are some remarkable points in his work, which even seem to anticipate some statements by Richard Middleton or Simon Frith. The core of his essay is the statement that there are three literatures: the 'official', the folk and what he calls 'the third one'. Even if Hernas did not intend to write about popular music, we cannot help thinking about what Frith wrote a couple of years later about three 'art worlds', three major groups that produce music and music evaluation: art (the 'bourgeois'), folk and commercial ${ }^{20}$. Even without investigating this matter any further, Hernas reminds us that there is a connection between this 'third literature' and the song form, which over the years grew more and more appreciated throughout society. Commercial literature as a mass medium, he states, first developed in England during the 18th century; in Poland, it appeared about one hundred years later, during the Romantic period, and, after some important cultural, social and political processes, it went through big changes. In particular, in the second

18 In this article we will not consider what was written after 1983, but let's remind here at least about the essays on Polish rock lyrics written by Halina Zgółkowa between 1984 and 1989 on literary journals like „Nurt” and „Polonistyka”, which remain a rather isolated case.

19 C. Hernas, Potrzeby i metody badania literatury brukowej, [in:] O wspótczesnej kulturze literackiej, vol. 1, eds. S. Żółkiewski, M. Hopfinger, Wrocław 1973, pp. 15-45.

20 S. Frith, Performing Rites. On the Value of Popular Music, Oxford 1996, pp. 35-42 (but the idea, as stated by Frith on p. 36, comes from Howard S. Becker and P. Bourdieu). Actually, Hernas writes that 'brukowa' ('bruk' means 'cobblestone') is the Polish term for 'rynkowa' ('rynek' is the market, so maybe we can translate 'brukowa' as 'commercial'). 
half of the 20th century, the collections of printed music were replaced by the records. „The laws of the market are most evident in the record business, where traditionally there exist a legal market, a semi-legal market and an illegal market" ${ }^{\prime 2}$. The following passage happened to be quite revolutionary: „Let's stop the presumption that [commercial literature - L.M.] is awkward, literarily wannabe, and non-fulfilling the requirements of certain poetics. This kind of reproach comes from the cultured classes, which refer to their own values and tastes and don't approve as a whole the immanent poetics which rules that kind of literature"22. Hernas's essay is considered the starting point for a history of popular literature, but in my opinion it could be taken as a starting point for a history of popular music in Poland as well ${ }^{23}$. However, while Hernas defends such literature, most of the scholars who approached the new field of popular literature studies after him remained limited within the frame of Polish literature academic research. As Katarzyna LeńskaBąk writes, they „were most of all scholars who, until then, had dealt with works of the so-called high literature. Thus, probably for this reason they often showed in their essays the tendency to differentiate, and most of all to compare popular literature with high literature"24.

And this is what in part Edward Balcerzan, Anna and Stanisław Barańczak did. They also came from the field of literature studies, but belonged to the same generation of the first Polish popstars, Czesław Niemen (1939-2004), Ewa Demarczyk (1941-2020) or Marek Grechuta (1945-2006), and they grew up with bigbit (the Polish name for rock and roll in the 60s). Not only were they employed at the Adam Mickiewicz University in Poznan, but they were poets and translators themselves. Anyway, they were aware of the fact that song lyrics cannot be discussed only with the instruments of literature studies. Sociology and semiology are the most frequently evoked auxiliary disciplines. „Popular literature as an object of scientific research requires the cooperation of two disciplines, sociology and poetics. To put it

${ }^{21}$ C. Hernas, op. cit., p. 29.

22 Ibidem, p. 19.

${ }^{23}$ It is actually quoted by G. Piotrowski, op. cit., p. 13.

${ }^{24}$ K. Łeńska-Bąk, Niekończące się spory o literaturę popularna, [in:] Zatargi, waśnie, konflikty: w perspektywie historycznej i kulturowej, ed. K. Łeńska-Bąk, Stromata Anthropologica, Vol. 10, Opole 2015, p. 132. 
simply, the »literariness « of this phenomenon is a matter of poetics, "popularity « is a matter of sociology”25. Semiology, on the other hand, „authorizes us to use the concept of language in relation to the perceptive habits of art users in general or to those of specific arts". Thus, in this matter we have to distinguish four languages, four 'worlds of signs': the language of poetry, the language of the song, the language of the perceptive habits of poetry recipients, and the language of the perceptive habits of the recipients of the song ${ }^{26}$. In the mass communication age, these four languages, writes Balcerzan, „overlap in their current state of development; paradoxically, despite a sense of mutual strangeness, or even hostility, a sense of kinship and solidarity appears among them. Singers begin to sing poems of outstanding poets, poets stop avoiding writing song lyrics"27.

Besides the literary element, there is another aspect in the background of the output of the researchers from Poznan University, namely: „the deep conviction of the need to analyse and understand the dominant mass culture model in the People's Republic of Poland, in order to avoid the deprivation of freedom, and in defence of the dignity of average citizens, who were losing their breath" 28 . Of course, this aspect could not be openly put on paper in these terms, but the criticism of the communist system is quite

25 E. Balcerzan, Przez znaki. Granice autonomii sztuki poetyckiej. Na materiale polskiej poezji współczesnej, Poznań 1972, p. 140. The passage about the language creations "approved in a given society" reminds us of the definition of 'genre' that Franco Fabbri published in 1981: "genre [is] a set of - real or possible - music events, whose course is governed by a definite set of socially accepted norms". Fabbri's theory was influenced by Eco's writings, in particular La struttura assente (1968), Le forme del contenuto (1971), Il segno (1973) and Trattato di semiotica (1975). See: F. Fabbri, I generi musicali. Una questione da riaprire, „Musica/Realtà” 1981, Vol. 4, pp. 43-66; idem, Genre Theories and Their Applications in the Historical and Analytical Study of Popular Music: A Commentary on My Publications, $\mathrm{PhD}$ Thesis, University of Huddersfield, 2012, http://eprints.hud.ac.uk/id/eprint/17528/ [accessed 17.05.2020].

26 E. Balcerzan, op. cit., p. 144.

27 Ibidem, p. 145.

28 I. Kiec, M. Traczyk, Popularne formy kultury w badaniach poznańskiej szkoły teoretycznej, „Studia z Kultury Popularnej” 2015, No. 1: Prolegomena do dziejów kultury popularnej w Poznaniu; http://fundacja-ikp.pl/studia/106/ [accessed 
evident, here. Balcerzan's poetry mostly explores the possibilities of language and its relations with reality. Barańczak and other poets from the group 'Nowa Fala' ('New Wave'), or Generation '68 (Adam Zagajewski and Ryszard Krynicki, among others) criticized the newspeak of the propaganda. The essays on songs, in Anna and Stanisław Barańczak's intentions, were also a way to work on topics like freedom and persuasion, and to show their mechanisms. Songs must be persuasive, and the average commercial song is built on falsity. Stanisław Barańczak suggests - although he does not write it explicitly - that songs work like propaganda: indeed, this is a perspective that reminds us of Adorno's writings on popular music. Surely, if compared to Adorno, the Polish author shows a deeper sensitivity and attention to this form of art, especially in his first short text about songs, Gesty piosenkarzy („The gestures of song performers”) ${ }^{29}$, where he presents popular music as the complex interaction of different forms of communication, „not only music and lyrics, but also performing techniques, gestures (even the most banalized) or the functions of interaction with the audience during a live concert" ${ }^{\prime 30}$. But three years later, in a longer essay, Piosenka a topika wolnosci („The song and the topic of freedom”), the author seems less indulgent towards popular music, maybe because of the different nature and destination of this work, published in a major literary journal. In this study, before analyzing the lyrics of contemporary songs, Barańczak puts down some theoretical premises, where he explains that song is a double-tracked form, lyrics and music being the tracks that have to be kept together - but what happened to the gestures or the performing techniques he wrote about in the former essay? In fact, here Barańczak is concentrated on the theme of freedom, and, similarly to Adorno, he concludes that mass culture is based on its absence. Quoting Erich Fromm, he states that songs represent an 'escape from freedom': their codes have to be simple, so that the masses can easily identify them. Developing his wife Anna's reflections published

17.05.2020]. A slight criticism of the effectiveness of a central control on popular culture was also present in: C. Hernas, op. cit., p. 30.

29 S. Barańczak, Gesty piosenkarzy, „Nurt” 1971, No. 11, p. 64.

30 K. Dźwinel, Stanisław Barańczak w kręgu piosenki. Część I: Badacz, „Piosenka” 2017, No. 5, p. 34. 
in an article one year before ${ }^{31}$, Stanisław Barańczak writes that all this comes from a sort of a 'semantic necessity' of the 'typical' song, which proceeds in the direction of a deprivation of freedom (despite some exceptions, namely songs which are not destined to the masses or the previously mentioned 'piosenka literacka') ${ }^{32}$. The author distinguishes two kinds of contemporary culture, even if he puts them between quotation marks: the 'high art' and the 'mass culture'. While in the former case the virtual recipient of the work is constructed with a focus on its activity and independence, within mass culture we basically have „a focus on the recipient's passivity and incapacitation" 33 . Despite the adoption of distance strategies and the tendency to reaffirm their non-artistic nature ${ }^{34}$, despite their catty definition as 'lyrics with an amplifier', the poet's knowledge of popular songs and his familiarity, as a translator, with song lyrics show how much he actually liked to mix high and low culture. It is impossible not to mention here that over the years Barańczak translated into Polish and published lyrics of very different sorts and in very different ways: Wilhelm Muller's Winterreise, Lorenzo Da Ponte's librettos for Mozart, Bob Dylan's or Lennon-McCartney's repertoire the result being always a redefinition of the borders between 'high' and 'low'. Besides, one of Balcerzan's main questions in Przez znaki („Through signs") was why, since the end of the 19th century, songs had enjoyed great

31 A. Barańczak, Konwencjonalność w piosence jako problem semantyczny, [in:] Formy literatury popularnej, ed. A. Okopień-Sławińska Wrocław 1973, pp. 173192. See also A. Barańczak's major work on popular songs lyrics, based on her $\mathrm{PhD}$ dissertation, but published much later: A. Barańczak, Słowo w piosence: poetyka współczesnej piosenki estradowej, Wrocław - Warszawa - Kraków - Gdańsk - Łódź 1983.

32 S. Barańczak, Piosenka i topika wolności, „Pamiętnik Literacki” 1965, No. 3 , p. 118.

33 Ibidem, p. 116.

34 See also the attitude of Italian intellectuals towards the end of the 1950s (J. Tomatis, Apocalittici e popolare. Gli intellettuali italiani e la canzone negli anni Cinquanta, „Il Ponte” 2017, Vol. 73, No. 2, p. 121; P. Ortoleva, Il secolo dei media, Milano 2009, p. 307). 
popularity, whereas poetry had not ${ }^{35}$, being aware that all in all "both song and poetry involved the same interpersonal communication channels" ${ }^{\prime \prime 6}$.

Of the three classical books which, between the 50s and the 60s, cast a new light on mass culture - Roland Barthes' Mithologies, Edgard Morin's L'esprit du temps and Umberto Eco's Apocalittici ed integrati - Balcerzan quotes only the first one, which in Poland appeared in 1970. Stanisław Barańczak quotes Morin and another work by Eco, La struttura assente (1968 - Polish translation: Pejzaż semiotyczny, 1972). Apocalittici ed integrati was, among the mentioned works, the most related to popular music, but its Polish translation only appeared in $2010^{37}$. Thus - in conclusion - when they started their reflection on popular music, Polish scholars did not really have a background of studies in this field. We may regret that not many of them followed Hernas's approach, and we may as well ask ourselves why, despite the absence of references to Adorno, Barańczak turned to be Adornian. The answer probably is that his attitude was due to the uneasiness he would have felt, as a young scholar, dealing with such 'guilty pleasures' in an academic environment.

\section{Bibliography}

Theodor W. Adorno (with George Simpson), Muzyka popularna, transl. J. Kasperski, „Res Facta Nova” 2015, No. 16.

Theodor W. Adorno, Sztuka i sztuki, compiled and prefaced by K. Sauerland, transl.

K. Krzemień-Ojak, PIW, Warszawa 1990.

Edward Balcerzan, Przez znaki. Granice autonomii sztuki poetyckiej. Na materiale polskiej poezji współczesnej, Wydawnictwo Poznańskie, Poznań 1972.

Anna Barańczak, Konwencjonalność w piosence jako problem semantyczny, [in:] Formy literatury popularnej: studia, ed. A. Okopień-Sławińska, Zakład Narodowy im. Ossolińskich, Wrocław 1973.

Anna Barańczak, Stowo w piosence: poetyka wspótczesnej piosenki estradowej, Zakład Narodowy im. Ossolińskich, Wrocław 1983.

Stanisław Barańczak, Gesty piosenkarzy, „Nurt” 1971, No. 11.

${ }^{35}$ E. Balcerzan, op. cit., p. 142

36 Ibidem, p. 267.

37 U. Eco, Apokaliptycy i dostosowani: komunikacja masowa i teorie kultury masowej, transl. M. Salwa, Warszawa 2010. 
Stanisław Barańczak, Piosenka i topika wolności, „Pamiętnik Literacki” 1965, No. 3. Krzysztof Biegański, Mała encyklopedia muzyki, ed. S. Śledziński, PWM, Warszawa 1968.

Tomash Dąbrowski, The Motif of Redemption in Walter Benjamin's Early Writings, „Telos. Critical Theory of the Contemporary”, 2.10.2012, https://www.telospress.com/the-motif-of-redemption-in-walter-benjamins-early-writings/. Kamil Dźwinel, Stanisław Barańczak w kręgu piosenki. Część I: Badacz, „Piosenka” 2017, No. 5.

Umberto Eco, Apocalittici e integrati. Comunicazioni di massa e teorie della cultura di massa, Bompiani, Milano 1964.

Umberto Eco, Prefazione, [in:] M.L. Straniero, S. Liberovici, E. Jona, G. De Maria, Le canzoni della cattiva coscienza, Bompiani, Milano 1964.

Franco Fabbri, I generi musicali. Una questione da riaprire, „Musica/Realtà” 1981, Vol. 4.

Franco Fabbri, Genre Theories and Their Applications in the Historical and Analytical Study of Popular Music: A Commentary on My Publications, PhD Thesis, University of Huddersfield, 2012, http://eprints.hud.ac.uk/id/eprint/17528/.

Simon Frith, Performing Rites. On the Value of Popular Music, Oxford University Press, Oxford 1996.

Czesław Hernas, Potrzeby i metody badania literatury brukowej, [in:] O wspótczesnej kulturze literackiej, Vol. 1, eds. S. Żółkiewski, M. Hopfinger, Zakład Narodowy imienia Ossolińskich - Wydawnictwo Polskiej Akademii Nauk, Wrocław 1973.

Anna Idzikowska-Czubaj, Rock w PRL-u. O paradoksach współistnienia, Wydawnictwo Poznańskie, Poznań 2011.

Jakub Kasperski, Fryderyk Chopin in Popular Instrumental Music, „Interdisciplinary Studies in Musicology" 2011, No. 9.

Izolda Kiec, Michał Traczyk, Popularne formy kultury $w$ badaniach poznańskiej szkoły teoretycznej, „Studia z Kultury Popularnej” 2015, No. 1: Prolegomena do dziejów kultury popularnej w Poznaniu; http://fundacja-ikp.pl/studia/106/. Zbigniew Kloch, Adam Rysiewicz, Piosenka [entry], [in:] Słownik literatury polskiej XX wieku, eds. A. Brodzka, M. Puchalska, M. Semczuk, A. Sobolewska, E. Szary-Matywiecka, Zakład Narodowy im. Ossolińskich, Wrocław Kraków - Warszawa 1992.

Leszek Kołakowski, Główne nurty marksizmu, p. 3: Rozkład, Instytut Literacki, Paris 1978. 
Magdalena Kwiatkowska, „Folk or Popular? Distinctions, Influences, Continuities”, Richard Middleton i David Horn, Cambridge, London, New York, New Rochelle, Melbourne, Sydney 1981 [review], „Muzyka” 1983, Vol. 28, No. 3

Katarzyna Łeńska-Bąk, Niekończące się spory o literaturę popularną, [in:] Zatargi, waśnie, konflikty: w perspektywie historycznej i kulturowej, ed. K. Łeńska-Bąk, Stromata Anthropologica, Vol. 10, Wydawnictwo Uniwersytetu Opolskiego, Opole 2015.

Leonardo Masi, Czym jest „muzyka lekka” i „muzyka ciężka”?, [in:] Ciężar i lekkość w kulturze. Estetyka - poetyka - style myślenia, ed. B. Pawłowska-Jądrzyk, Wydawnictwo UKSW, Warszawa 2016.

Wacław Panek, Mały słownik muzyki rozrywkowej, Zarząd Główny Związku Polskich Autorów i Kompozytorów ZAKR, Warszawa 1986.

Renata Pasternak-Mazur, No Country for Sheer Entertainment. Cultural Politics of Socialist Poland, Its Conceptual Scheme, and Vision of Popular Music, [in:] Made in Poland: Studies in Popular Music, ed. P. Gałuszka, Routledge, New York - Abingdon 2020.

Tomasz Misiak, Muzyka poważna, muzyka popularna. Dualizm współczesnej kultury muzycznej z perspektywy współczesnej socjologii muzyki, „Muzyka” 1983, Vol. 28, No. 4.

Peppino Ortoleva, Il secolo dei media, Il Saggiatore, Milano 2009.

Grzegorz Piotrowski, Muzyka popularna. Nasłuchy i namysty, PIW, Warszawa [cop. 2016].

Słownik realizmu socjalistycznego, eds. Z. Łapiński, W. Tomasik, TAiWPN Universitas, Kraków [cop. 2004].

Małgorzata Sułek, Pieśni masowe o Nowej Hucie, „Zeszyty Naukowe Towarzystwa Doktorantów Uniwersytetu Jagiellońskiego. Nauki Humanistyczne” 2010, No. 1.

Jacopo Tomatis, Apocalittici e popolare. Gli intellettuali italiani e la canzone negli anni Cinquanta, „Il Ponte” 2017, Vol. 73, No. 2.

Maja Trochimczyk, W strone muzykologii narodowej: Uczeni wobec muzyki polskiej, „Muzyka” 2002, No. 3-4. 


\section{The Beginnings of Popular Music Studies in Poland (Hernas, Balcerzan and Barańczak)}

In their 'pre-historical' phase (1968-1983), Popular Music Studies in Poland displayed a specificity resulting from a different political and cultural history and, to certain extent, from cultural isolation during the period of state socialism. Adorno's works on popular music remained probably unknown until the last two decades to the majority of Polish cultural historians, causing them to come up with their own ideas. The article aims at reconstructing how the first striking analyses of popular music in Poland came from the field of literature studies, in particular from baroque literature scholar Czesław Hernas, poet and scholar Edward Balcerzan, poet, translator and literary critic Stanisław Barańczak and from his wife Anna Barańczak.

Keywords: popular music studies, sung poetry, Poznań theoretical school, reception of Adorno in Poland 